\title{
Determining the Suitability of Two Different Statistical Techniques in Shallow Landslide (Debris Flow) Initiation Susceptibility Assessment in the Western Ghats
}

\author{
Ninu Krishnan M. V. ${ }^{1}$, Pratheesh P. ${ }^{2}$, Rejith P. G. ${ }^{3}$, Hamza V. ${ }^{1,4}$ \\ ${ }^{1}$ State Emergency Operation Centre (SEOC), Kerala State Disaster Management Authority, Institute of Land and \\ Disaster Management, Kerala, India \\ ${ }^{2}$ Centre for Geoinformation Science and Technology, University of Kerala, Kariavattom, Kerala, India \\ ${ }^{3}$ Department of Environment and Climate Change, Government of Kerala, Kerala, India \\ ${ }^{4}$ Department of Applied Geology, School of Engineering and Science, Curtin University of Technology, Sarawak, \\ Malaysia
}

Corresponding author:

Hamza V., State Emergency Operation Centre (SEOC), Kerala State Disaster Management Authority, Institute of Land and Disaster Management, P.T.P Nagar, Thiruvanathapuram, Kerala, India - 695038

E-mail:vijithh@gmail.com

\begin{abstract}
In the present study, the Information Value (InfoVal) and the Multiple Logistic Regression (MLR) methods based on bivariate and multivariate statistical analysis have been applied for shallow landslide initiation susceptibility assessment in a selected subwatershed in the Western Ghats, Kerala, India, to determine the suitability of geographical information systems (GIS) assisted statistical landslide susceptibility assessment methods in the data constrained regions. The different landslide conditioning terrain variables considered in the analysis are geomorphology, land use/land cover, soil thickness, slope, aspect, relative relief, plan curvature, profile curvature, drainage density, the distance from drainages, lineament density and distance from lineaments. Landslide Susceptibility Index (LSI) maps were produced by integrating the weighted themes and divided into five landslide susceptibility zones (LSZ) by correlating the LSI with general terrain conditions. The predictive performances of the models were evaluated through success and prediction rate curves. The area under success rate curves (AUC) for InfoVal and MLR generated susceptibility maps shows $84.11 \%$ and $68.65 \%$, respectively. The prediction rate curves show good to moderate correlation between the distribution of the validation group of landslides and LSZ maps with AUC values of 0.648 and 0.826 respectively for MLR and InfoVal produced LSZ maps. Considering the best fit and suitability of the models in the study area by quantitative prediction accuracy, LSZ map produced by the InfoVal technique shows higher accuracy, i.e. $82.60 \%$, than the MLR model and is more realistic while compared in the field and is considered as the best suited model for the assessment of landslide susceptibility in areas similar to the study area. The LSZ map produced for the area can be utilised for regional planning and assessment process, by incorporating the generalised rainfall conditions in the area.
\end{abstract}

Keywords: Western Ghats, shallow landslide, information value, multiple logistic regression, susceptibility assessment.

\section{Introduction}

Landslides are considered as the most disastrous hydro-geological phenomena which frequently occur in association with extreme climatic and geologic events. Most of the mountainous terrains in tropical and subtropical environments are characterised by one or another type of mass movements. Assessment of 
landslide susceptibility zones enables the society to develop proper planning in the developmental activities. The research of landslides and landslide prone areas has focused on the risks and hazards related to them, their consequences and the factors that govern their occurrence (Pourghasemi et al., 2013). In developing countries, the landslide susceptibility assessment is the only possibility of overcoming the consequences, risks and hazards associated with this problem. Landslide hazard assessment can be a vital tool to understand the basic characteristic of the terrain that is prone to failure and was first introduced by Varnes (1984) as landslide hazard zonation to quantitatively measure the landslide hazard. The term susceptibility is commonly used to identify the location of potential landslides in a given region based on a set of terrain characteristics (Carrara, 1983; Zezere, 2002; Dahal et al., 2008; Ercanoglu and Temiz, 2011; Yilmaz et al., 2012). The probability of spatial occurrence of future landslides is reflected in a terrain failure susceptibility map, which indicates the potential starting zones. The rapid development of spatial information technologies, especially the availability of high resolution remote sensing images, digital elevation models and powerful application of geographical information systems (GIS) together made great advancement in mapping and assessment of landslide susceptibility of an area using different methods (Carrara et al., 1991; Brenning, 2005; van Westen et al., 2006; Akbar and Ha, 2011; Akgun et al., 2012; Althuwaynee et al., 2010; Pourghasemi et al., 2013; Ozdemir and Altural, 2013). The process of GIS-aided landslide susceptibility mapping at present involves several methods that can be considered as either qualitative or quantitative. Qualitative methods depend on expert opinions, and are often useful for regional assessments (Aleotti and Chowdhury, 1999; van Westen et al., 2003). To remove subjectivity in qualitative analysis, various statistical methods have been used in LSZ studies. The aim of these methods is to identify areas that are susceptible to future landsliding, based on the knowledge of past landslide events, geological attributes, terrain parameters and other environmental conditions that are associated with the presence or absence of such phenomena. Comparison of various methods used for assessing landslide susceptibility of a terrain can be found at Aleotti and Chowdhury (1999), Guzzetti et al. (1999), van Westen (2000) and Huabin et al. (2005).

Landslides affect large parts of the hilly terrain in India, especially, the Himalayas, the Western Ghats, the Eastern Ghats and the Vindhyans (Nagarajan et al., 1998; Prasannakumar and Vijith, 2012). Deforestation and anthropogenic activities, together with the non-sustainable developmental projects and destructive practices, have recently increased the frequency of landslides and mass wasting in the Himalayas and the Western Ghats regions, necessitating predictive and mitigative measures. Number of studies have been reported from various parts of India, using different techniques and approaches, related to the landslide risk reduction by systematic mapping and scientific analysis of landslide susceptible areas (Thampi et al., 1998; Arora et al., 2004; Sarkar and Kanungo, 2004; Saha et al., 2005; Pandey et al., 2007; Vijith and Madhu, 2008; Mathew et al., 2009; Das et al., 2010; Kundu et al., 2013; Kannan et al., 2014; Vijith et al., 2014). Though number of studies have been conducted to identify and map landslide susceptibility zones in these regions, no studies have commented on the suitability of a method and approach, which have been replicated for other regions where similar geoenvironmental conditions exist. The present study aims to assess the usability of GIS assisted statistical (bivariate and multivariate) landslide susceptibility models in a data deficient hilly terrain in the Western Ghats of Kerala, India, which witnesses severe land degradation due to landslides (debris flows) during the monsoon periods. Landslides in the Western Ghats, which comes second to the Himalayan region, can be categorised as a monsoon related phenomenon. The trigger for the landslides in the Western Ghats was at the period of heavy rainfall, and as there had been little effort to assess or predict the events, damage was extensive (Nagarajan et al., 1998; Thampi et al., 1998; Vijith et al., 2007; Kuriakose et al., 2009; Prasannakumar and Vijith, 2012). The analysis techniques which are used for the preparation of landslide susceptibility zonation maps are (a) information value (InfoVal) and (b) multiple logistic regression (MLR). The application of these methods can be found at Carrara (1983), van Westen (1997), Wu et al. (2000), Zezere (2002), Ayalew and Yamagishi (2005), Saha et al. (2005), Duman et al. (2006), Gorsevski et al. (2006), Vijith et al. (2007), Bhai et al. (2010, 2011), Nandi and Shakoor (2010), Akgun (2012), Devkota et al. (2013).

\section{Study area}

The study area lies between latitude $9^{\circ} 38^{\prime} 28^{\prime \prime}$ and $9^{\circ} 48^{\prime} 25^{\prime \prime}$ and longitude $76^{\circ} 55^{\prime} 53^{\prime \prime}$ and $77^{\circ} 43^{\prime} 31^{\prime \prime}$ on the western slopes of the Western Ghats, the upland catchment of the River Meenachil, covering a total area of $154.99 \mathrm{~km}^{2}$ (Fig. 1). The areas are highly undulating; maximum elevation of the terrain exceeds $1,180 \mathrm{~m}$ above sea level (asl), which occupies portions of the Peermade plateau in Kerala. Geologically the area is made up of hard crystalline rocks, in which charnockite occupies $93 \%$ of the total area followed by biotite gneiss, dolerite, pink/gray granite and quartzite. The major geomorphic features present in the area are plateau, side slope plateau, denudational hills and denudational slope, which shows varying terrain inclinations from plain area to nearly vertical areas with slope, exceeds more than $60^{\circ}$ with a general west slope. The debris flows which occurred in the study area show a climatic signal: monsoon (June-November) rainfall induced debris flows from the steep slopes of the mountain ranges with an elevation range $>250 \mathrm{~m}$ occur every year after continuous rainfall of $24 \mathrm{~h}$, which exceeds $250 \mathrm{~mm} /$ day. During the phenomena, loose, 

in the Western Ghats

unconsolidated soil and earth material that rest on the rugged hills having steep, long side slopes move

down the slope, which destroy all the things on the path (Fig. 2).

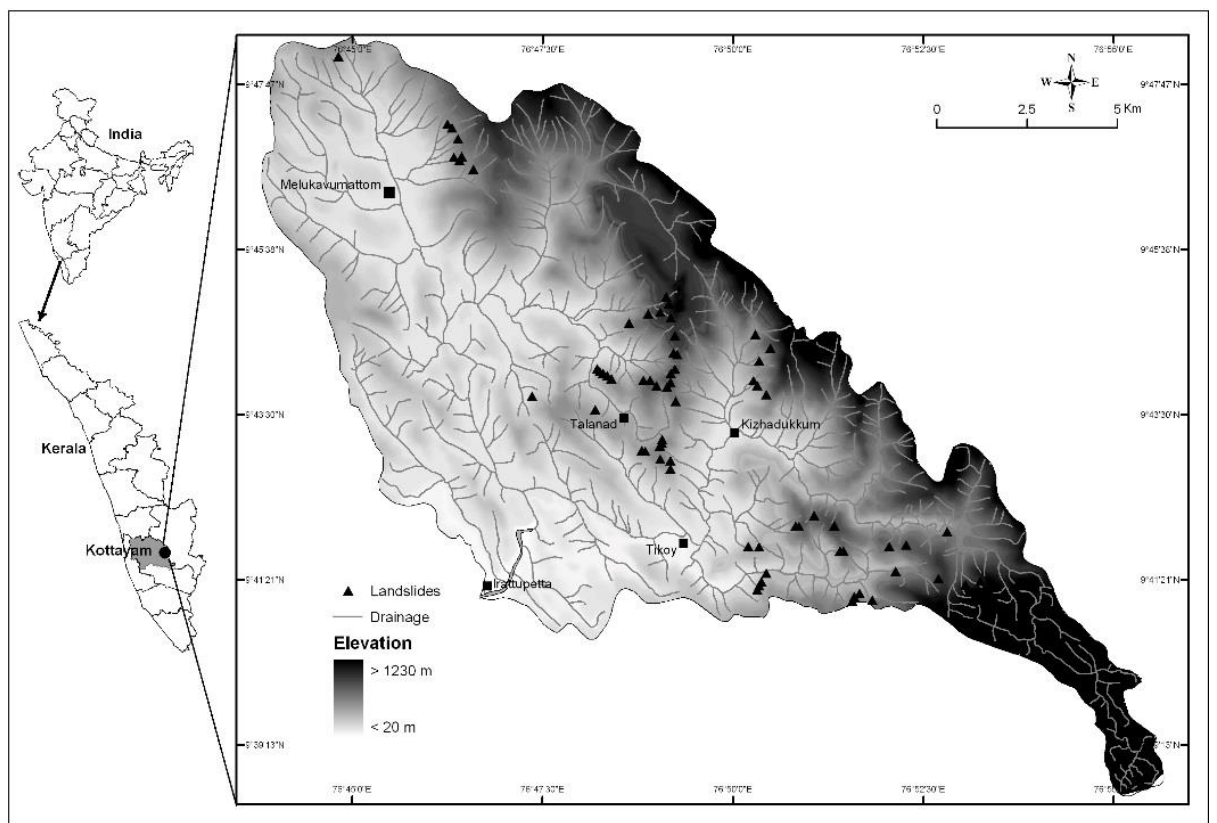

Figure 1. Study area location map.
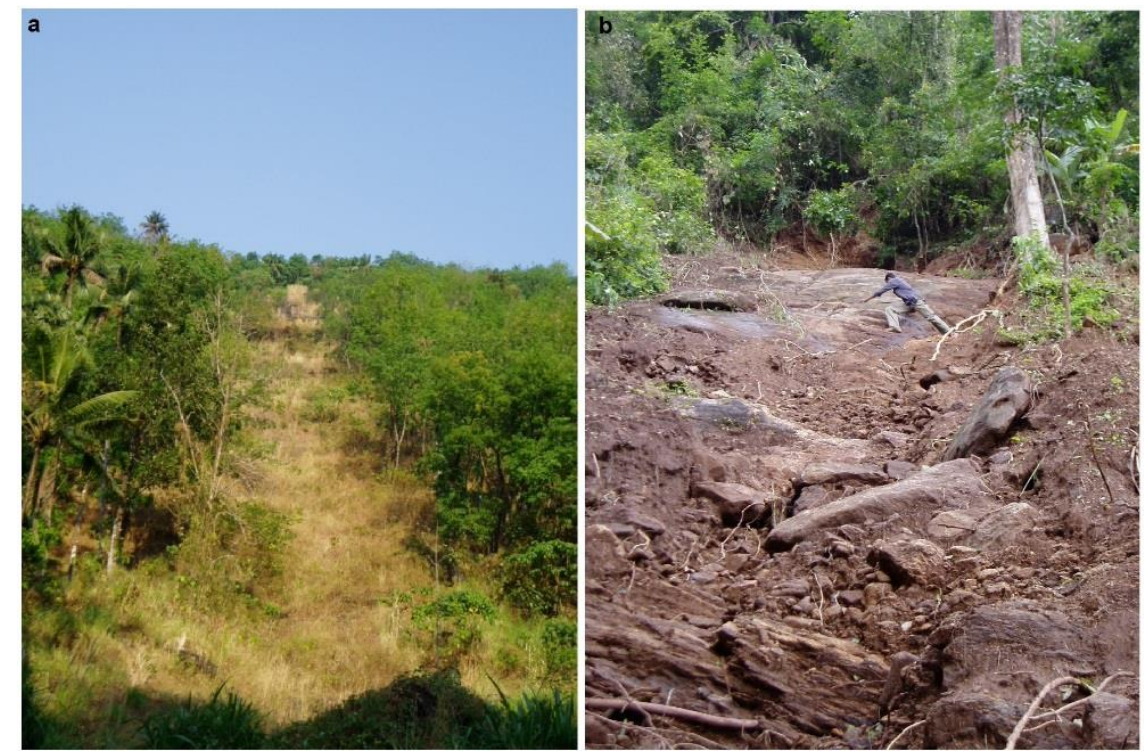

Figure 2. Image showing different landslide occurrences in the study area.

\section{Methodology}

\subsection{Generation of terrain conditioning geo- environmental variables}

The susceptibility mapping was performed using previous landslide locations as the crucial dependent variable and different thematic layers as independent variables. The geo-environmental variables comprising several themes used in the landslide susceptibility assessment as independent variables were derived from topographical maps, interpretation of remote sensing data (IRS P6 LISS III), geological map produced by the Geological Survey of India and detailed field surveys on a scale of 1:50,000. The entire study area covering $154.99 \mathrm{~km}^{2}$ was converted into a raster dataset having 387,460 pixels with a resolution of $20 \mathrm{~m} \times 20 \mathrm{~m}$. The most crucial theme that represents former landslides was collected by detailed field survey and located using a global positioning system (GPS). The previous landslide locations are a prerequisite to perform statistical analysis in GIS for assessing the relationship between the landslides and influencing parameters (Guzzetti et al., 1999; Duman et al., 2006; Vijith et al., 2007; Prasannakumar and Vijith, 2012). A total of 80 landslide points were located from the field and by applying a random partition technique 54 landslides were chosen for the preparation of landslide susceptibility zonation maps, and 26 were kept for assessing the predictive capacity of the landslide susceptibility maps produced. The thematic data 
layers prepared include geomorphology, land use/land cover, soil thickness, slope, aspect, relative relief, plan and profile curvatures, drainage density, distance from drainages, lineament density and distance from lineaments and are described below.

Geomorphology, which exhibit the surface forms and features present in the terrain, will provide vital information about its susceptibility to different denudational processes (Thampi et al., 1998; Guinau et al., 2005). The geomorphological feature identified includes plateau, side slope plateau, denudational hill, escarpment, denudational slope, valley fill, residual mounds, pediment and water body (Fig. 3a). Lithology of the area is found to be monolithic in nature, and more than $93 \%$ of the area is covered by charnockite of the Precambrian age with minor variations and less weathering. Lithology was not considered in the present analysis because most of the landslide activity in the area is shallow and, unlike in the Himalayan region, the basement lithology was not involved in the landslide process. Land use/land cover of the area represents a general vegetation pattern based on the terrain characteristics of the area, and the role of land use/land cover in conditioning the terrain for landsliding was studied by several researchers and is reported in various scientific papers (Saha et al., 2005; Dahal et al., 2008; Akgun, 2012, Pourghasemi, et al. 2013). Nine categories of land use/land cover types were identified in the study area, and they are rocky outcrops, grasslands, bushes and shrubs, tea plantations, rubber plantation, crop land, cleared/barren area, built-up-land and water body (Figure 3b). In a mountainous terrain, the development of soil will be very fast due to denudation activities; and most of the soil was transported to downstream areas due to natural processes like soil erosion and landslides. The spatial distribution of soil thickness was assessed by detailed field survey and found to be varying from $35 \mathrm{~cm}$ to $4.29 \mathrm{~m}$ (Figure 3c), in which the maximum thickness was found in the western boundary of the study area with gently sloping terrain.

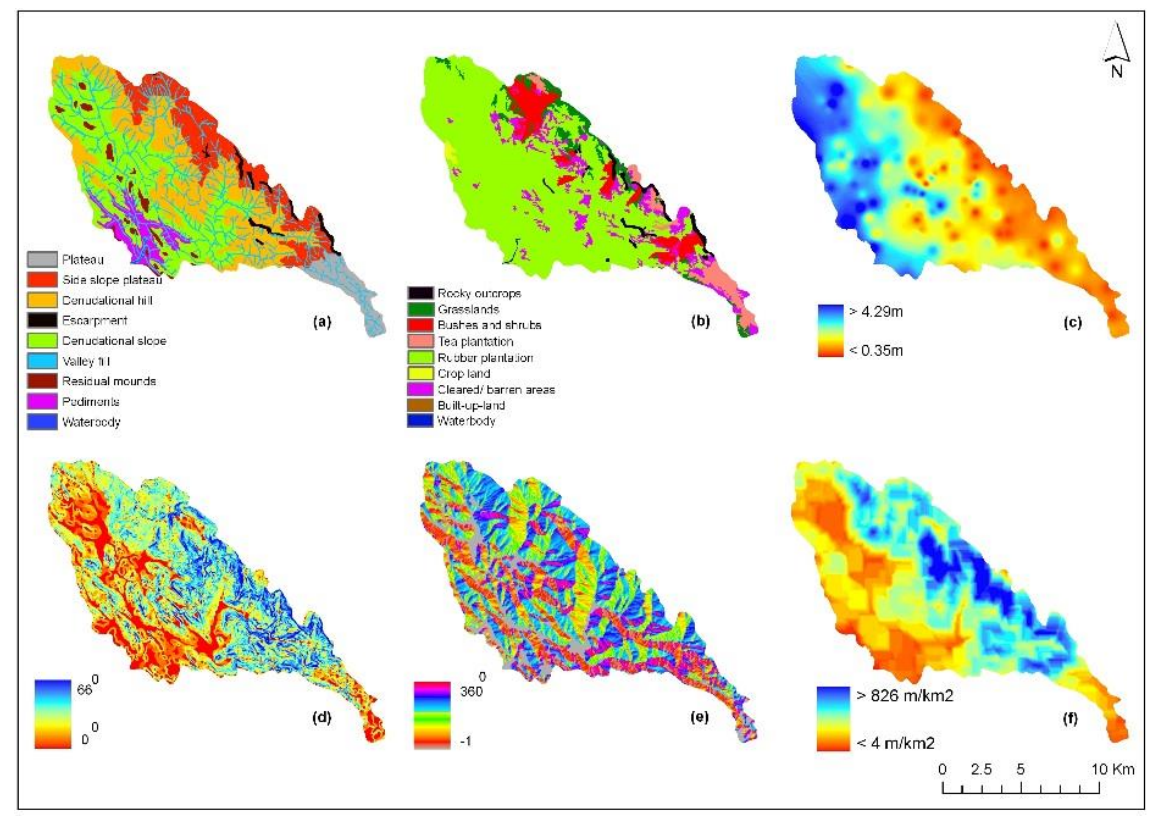

Figure 3. Terrain conditioning factors used in the analysis: (a) geomorphology; (b) land use/land cover; (c) soil thickness; (d) slope; (e) aspect; $(f)$ relative relief.

The most crucial layer in all the landslide susceptibility assessment and modelling is the slope of the terrain because landslides in any terrain are directly controlled by the slope of a particular place (Zezere, 2002; Guinau et al., 2005; Nefeslioglu et al., 2008; Akgun et al., 2012; Yilmaz et al., 2012; Devkota et al., 2013). Surface contours of $20 \mathrm{~m}$ interval digitised from the Survey of India topographic map were used to generate the elevation surface of the study area from which the important terrain variables such as slope, aspect, terrain curvatures and relative relief were derived. The generated slope map (Fig. 3d) shows a range of values between $0-66^{\circ}$, with a mean slope of $17^{\circ}$. The aspect map indicates the direction of maximum slope of the terrain surface, which along with the slope angle makes the terrain influenced by precipitation, exposition to sunlight, etc. (Gokceoglu and Aksoy, 1996; Saha et al., 2005; Akgun et al., 2012). The aspect map of the area was divided into nine classes, namely, Flat, N, NE, E, SE, S, SW, W and NW (Fig. 3e). The slope curvatures are an important variable that controls the superficial and subsurface hydrological regime of the slope, erosion and deposition rate, and soil characteristics (Yesilnacar and Topal, 2005; Gorsevski et al., 2006). The plan and profile slope curvatures (Fig. 4g and Fig. 4h) are divided into three classes, namely concave, flat and convex slopes as represented by negative, zero and positive values. Relative relief of the terrain indicates the changes in elevation in the unit area, and the generated relative relief (Fig. 3f) of the terrain varies from $4 \mathrm{~m} / \mathrm{km}^{2}$ to $826.49 \mathrm{~m} / \mathrm{km}^{2}$, with a mean and standard deviation of $279.02 \mathrm{~m} / \mathrm{km}^{2}$ and 
$152.39 \mathrm{~m} / \mathrm{km}^{2}$, respectively. Drainage density gives an indirect measure of runoff conditions and terrain dissection, which has a great significance in conditioning the terrain for the landslide process (Sarkar and Kanungo, 2004; Saha et al., 2005; Yesilnacar and Topal, 2005; Vijith et al., 2007), and the drainage density calculated for the study area shows variation in length of drainages in unit area ranging from $211 \mathrm{~m} / \mathrm{km}^{2}$ to $4,343 \mathrm{~m} / \mathrm{km}^{2}$ (Fig. $4 \mathrm{i}$ ).
The distance from drainages (Fig. 4j) calculated in the study area ranges from 0 to $752 \mathrm{~m}$, which indicates well developed, closely spaced drainage networks in mountainous area. The lineaments represent the plane of weakness on the surface, where the strength of slope material has been reduced, eventually resulting in slope failure. In the present study, lineament density and distance from lineaments were prepared and are shown in Figure 4k and Figure 41.

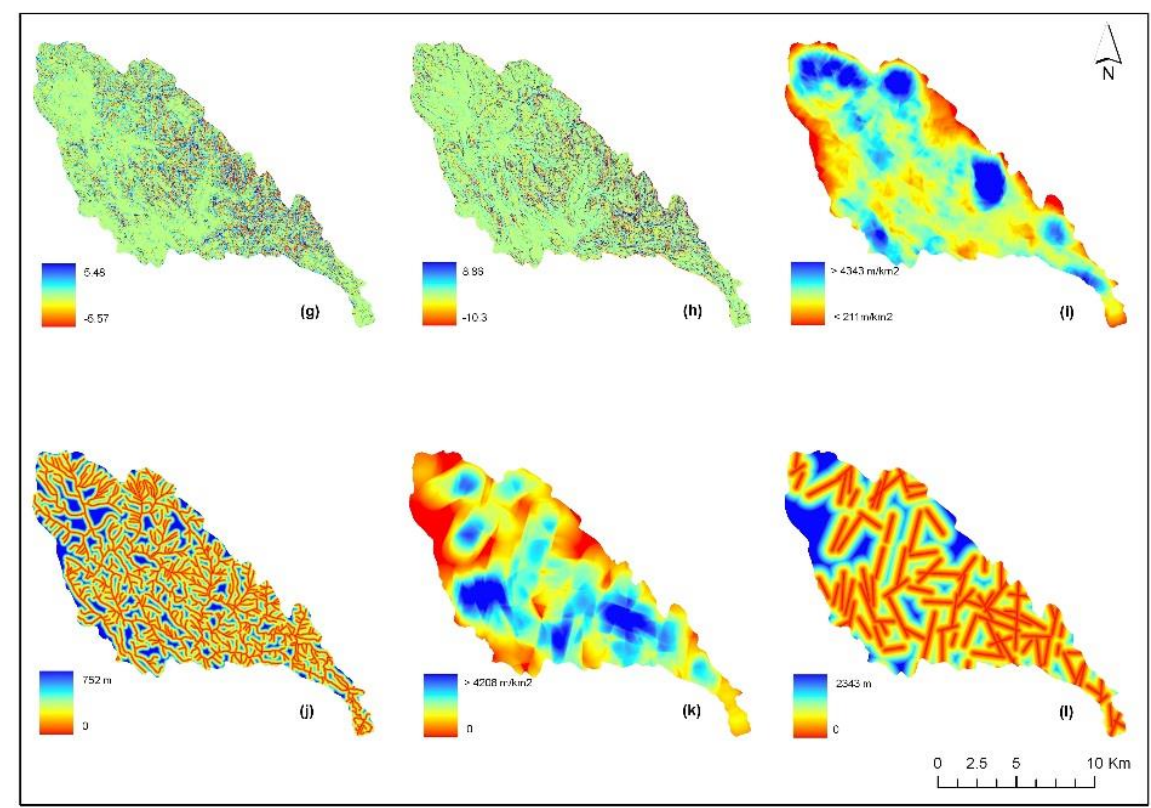

Figure 4. Thematic data layers: $(g)$ plan curvature; $(h)$ profile curvature; $(i)$ drainage density; $(j)$ distance from drainages; ( $k$ ) lineament density; ( $l$ ) distance from lineaments.

\subsection{Landslide susceptibility assessment techniques}

\subsubsection{Information Value (InfoVal)}

The landslide susceptibility assessment was fulfilled using a data-driven approach: the Information Value Method (van Westen, 1997; Wu et al., 2000; Zezere, 2002). The Information Value Method (InfoVal) is a simple indirect statistical approach that has the advantage of assessing landslide susceptibility in an unbiased way. The method allows the quantified prediction of susceptibility by means of a score, even on terrain units that are not yet affected by landslide occurrence. Each instability factor is crossed with the landslide distribution, and weighting values based on landslide densities are computed for each parameter class, as it happens with all bivariate statistical methods. The method implies a prior definition of terrain units and the selection of a set of instability factors. In this method, the information value for each parameter class is determined by the following equation $\mathrm{Wi}$ :

$$
\begin{aligned}
W i=\log (\text { Densclass/Desnsmap) } & \\
= & \log [(\operatorname{Npix}(\mathrm{Si}) / N \operatorname{Nix}(N i)) \\
& /\left(\sum_{i=1}^{n} N \operatorname{Nix}(\mathrm{Si}) /\left(\sum_{i=1}^{n} N \operatorname{Nix}(N i)\right)\right]
\end{aligned}
$$

where $W i$ is the weight for the $i^{\text {th }}$ class of a particular thematic map (i.e. plateau or side-slope plateau, or escarpment in the thematic map 'Geomorphology'), Densclass is the failure density in the factor class, Densmap is the failure density within the whole study area, $\operatorname{Npix}(\mathrm{Si})$ is the number of failed pixels in the $i^{\text {th }}$ factor class, $N p i x(N i)$ is the number of pixels in the $i^{\text {th }}$ factor class, and $n$ is the number of classes in the thematic map.

\subsubsection{Multiple Logistic Regression (MLR)}

Logistic regression involves a multivariate regression between a dependent variable and several independent variables (Atkinson and Massari, 1998; Hosmer and Lemeshow, 2000). Logistic regression is worthwhile to predict the presence or absence of a characteristic or outcome based on the values of predictor variables. In the case of landslide susceptibility mapping, the purpose of logistic regression is to find the best-fitting model to describe the relationship between the presence or absence of a landslide (the dependent variable) and a set of independent parameters (Bhai et al., 2010, 2011; Nandi and Shakoor, 2010; Akgun, 2012; Devkota et al., 2013). A binary dependent variable was used to represent the presence or absence of a landslide. Coefficients determined in the logistic regression can be used to estimate ratios for each of the independent variables. The logistic model representing the 
maximum likelihood regression model can be expressed in its simplest form as

$$
\mathrm{P}=\frac{1}{1+e^{-z}}
$$

where $P$ is the estimated probability of an event occurring. Because $Z$ (linear logistic model) can vary from $-\infty$ to $+\infty$, the probability varies from 0 to 1 as an S-shaped curve. Parameter $Z$ is defined as

$$
\mathrm{Z}=B_{0}+B_{1} X_{1}+B_{2} X_{2}+\ldots+B_{n} X_{n}
$$

where $B_{0}$ is the intercept and $n$ is the number of independent variables, $B_{i}(i=0,1,2, \ldots, n)$ is the slope coefficient, and $X_{i}(i=0,1,2, \ldots, n)$ is the independent variable. Based on equation (2) and equation (3), the logistic regression can be written in the following extended form:

$$
\operatorname{Logit}(\mathrm{P})=\frac{1}{1+e^{B 0+B 1 X 1+B 2 X 2+\cdots+B n X n}}
$$

\section{Analysis of the role of terrain conditioning factors}

In order to assess the contribution of each geoenvironmental variables in conditioning the terrain failure, landslide initiation locations kept for the LSZ map preparation were crossed with each variable, and the analysis was done in bivariate and multivariate statistical methods. Unlike the developed regions, the study area lacks detailed database of terrain features and historic landslide details. In bivariate analysis, InfoVal method and in multivariate analysis, multiple logistic regression (MLR) modelling techniques were used to assess the role of each terrain conditioning factor and also to identify the suitability of the landslide susceptibility assessment methodology in terrains similar to the study area. The analysis was initiated with converting all the data layers into raster format and also the continuous variables to discrete variables by the expert classification criteria to use in the InfoVal analysis technique. In the bivariate statistical analysis, all the independent variables used are either classified into different classes or into two classes for analysing each class's role in making the area susceptible to landslide. Using equation (1), weights of individual feature class were calculated by the number of landslide pixels falling in each class of the thematic data layers. In MLR, using the statistical software SPSS (version 11.5), pervious landslide locations are kept as the dependent variable (presence and absence) to execute the calculations. The calculated weights for individual feature classes are presented in Table 1, and in each case, the higher the derived weight values of predictive parameters classes are, the more contribution is attributed towards the making the terrain susceptible to landslides. This criterion is common to weights derived through InfoVal and MLR techniques. Hence, weight values of each parameter classes, which indicate the role of

\begin{tabular}{|c|c|c|c|c|c|}
\hline & Feature / Class & $\begin{array}{c}\text { Landslide } \\
\text { (Pixel) }\end{array}$ & $\begin{array}{c}\text { Area } \\
\text { (Pixel) }\end{array}$ & $\begin{array}{c}\text { InfoVal weight } \\
\text { (In) }\end{array}$ & $\begin{array}{c}\text { MLR weight } \\
\text { (ß) }\end{array}$ \\
\hline \multirow{9}{*}{ Geomorphology } & Plateau & 0 & 18,458 & $-3.0 *$ & -11.237 \\
\hline & Side-slope plateau & 14 & 60,303 & 0.512 & 5.510 \\
\hline & Denudational hill & 32 & 103,737 & 0.797 & 8.094 \\
\hline & Escarpment & 0 & 67,640 & $-3.0^{*}$ & $0^{\#}$ \\
\hline & Denudational slope & 2 & 107,278 & -2.0 & 6.649 \\
\hline & Valley fill & 6 & 64,408 & -0.400 & $0^{\#}$ \\
\hline & Residual mounds & 0 & 8,781 & $-3.0^{*}$ & $0^{\#}$ \\
\hline & Pediment & 0 & 17,338 & $-3.0 *$ & $0^{\#}$ \\
\hline & Water body & 0 & 393 & $-3.0^{*}$ & $0^{\#}$ \\
\hline \multirow{9}{*}{ Land use } & Rocky outcrops & 0 & 8,608 & $-3.0^{*}$ & -1.92 \\
\hline & Grass land & 3 & 21,398 & 0.008 & $0^{\#}$ \\
\hline & Bushes and shrubs & 9 & 30,188 & 0.763 & $0^{\#}$ \\
\hline & Tea plantation & 1 & 18,825 & -0.961 & 0.782 \\
\hline & Rubber plantation & 31 & 268,773 & -0.186 & $0^{\#}$ \\
\hline & Crop land & 0 & 1,789 & $-3.0^{*}$ & $0^{\#}$ \\
\hline & Cleared/barren area & 10 & 37,416 & 0.653 & $0^{\#}$ \\
\hline & Built-up land & 0 & 70 & $-3.0^{*}$ & $0^{\#}$ \\
\hline & Water body & 0 & 393 & $-3.0^{*}$ & $0^{\#}$ \\
\hline \multirow{4}{*}{ Soil Thickness } & $0-1 \mathrm{~m}$ & 7 & 69,286 & -0.319 & -5.113 \\
\hline & $1-2.5 \mathrm{~m}$ & 40 & 199,009 & 0.368 & -4.787 \\
\hline & $2.5-3.5 \mathrm{~m}$ & 4 & 101,885 & -1.264 & -4.968 \\
\hline & $>3.5 \mathrm{~m}$ & 3 & 17,280 & 0.222 & $0^{\#}$ \\
\hline
\end{tabular}
each feature, are detailed below.

Table 1. InfoVal weights and logistic regression coefficients of the terrain conditioning factors 

in the Western Ghats

\begin{tabular}{|c|c|c|c|c|c|}
\hline & Feature / Class & $\begin{array}{l}\text { Landslide } \\
\text { (Pixel) }\end{array}$ & $\begin{array}{c}\text { Area } \\
\text { (Pixel) }\end{array}$ & $\begin{array}{c}\text { InfoVal weight } \\
\text { (ln) }\end{array}$ & $\begin{array}{c}\text { MLR } \\
\text { weight }(\beta)\end{array}$ \\
\hline \multirow{9}{*}{ Slope } & $0-5^{0}$ & 2 & 74,203 & -1.640 & -1.594 \\
\hline & $5-10^{0}$ & 2 & 41,107 & -1.049 & -0.660 \\
\hline & $10-15^{0}$ & 2 & 50,952 & -1.264 & -0.497 \\
\hline & $15-20^{0}$ & 7 & 56,791 & -0.120 & -0.004 \\
\hline & $20-25^{0}$ & 16 & 53,984 & 0.757 & 1.544 \\
\hline & $25-30^{0}$ & 9 & 44,173 & 0.382 & 1.487 \\
\hline & $30-35^{0}$ & 4 & 30,997 & -0.074 & -2.150 \\
\hline & $35-40^{0}$ & 3 & 19,768 & 0.087 & 0.540 \\
\hline & $>40^{0}$ & 9 & 15,485 & 1.430 & $0^{\#}$ \\
\hline \multirow{9}{*}{$\begin{array}{l}\text { Aspect } \\
(0.003)\end{array}$} & Flat & 1 & 46,426 & -1.864 & \\
\hline & $\mathrm{N}$ & 9 & 29,729 & 0.778 & \\
\hline & $\mathrm{NE}$ & 2 & 43,241 & -1.100 & \\
\hline & $E$ & 3 & 34,333 & -0.464 & \\
\hline & SE & 3 & 33,943 & -0.452 & \\
\hline & $\mathrm{S}$ & 4 & 43,540 & -0.414 & \\
\hline & SW & 11 & 76,299 & 0.036 & \\
\hline & $\mathrm{W}$ & 10 & 51,038 & 0.343 & \\
\hline & NW & 11 & 28,911 & 1.006 & \\
\hline \multirow{7}{*}{$\begin{array}{c}\text { Relative Relief } \\
\qquad(0.008)\end{array}$} & $0-50 \mathrm{~m} / \mathrm{km}^{2}$ & 0 & 5,403 & $-3.0 *$ & \\
\hline & $50-100 \mathrm{~m} / \mathrm{km}^{2}$ & 0 & 46,972 & $-3.0 *$ & \\
\hline & $100-200 \mathrm{~m} / \mathrm{km}^{2}$ & 1 & 96,473 & -2.595 & \\
\hline & $200-300 \mathrm{~m} / \mathrm{km}^{2}$ & 11 & 71,828 & 0.096 & \\
\hline & $300-400 \mathrm{~m} / \mathrm{km}^{2}$ & 20 & 80,814 & 0.576 & \\
\hline & $400-500 \mathrm{~m} / \mathrm{km}^{2}$ & 12 & 52,808 & 0.491 & \\
\hline & $>500 \mathrm{~m} / \mathrm{km}^{2}$ & 10 & 33,220 & 0.772 & \\
\hline \multirow{3}{*}{$\begin{array}{c}\text { Plan Curvature } \\
(-1.471)\end{array}$} & Concave & 15 & 210,426 & -0.667 & \\
\hline & Flat & 36 & 168,220 & 0.431 & \\
\hline & Convex & 3 & 8,814 & 0.895 & \\
\hline \multirow{3}{*}{$\begin{array}{c}\text { Profile Curvature } \\
(-1.091)\end{array}$} & Concave & 37 & 216,400 & 0.207 & \\
\hline & Flat & 14 & 145,762 & -0.369 & \\
\hline & Convex & 3 & 25,298 & -0.158 & \\
\hline \multirow{3}{*}{$\begin{array}{c}\text { Drainage Density } \\
(\mathbf{1 0 . 8 3 3 )}\end{array}$} & $0-2,000 \mathrm{~m} / \mathrm{km}^{2}$ (low) & 43 & 269,458 & 0.138 & \\
\hline & $2,000-3,000 \mathrm{~m} / \mathrm{km}^{2}$ (moderate) & 11 & 101,392 & -0.247 & 7.587 \\
\hline & $>3,000 \mathrm{~m} / \mathrm{km}^{2}$ (high) & 0 & 16,084 & $-3.0 *$ & $0^{\#}$ \\
\hline \multirow{5}{*}{$\begin{array}{c}\text { Distance from } \\
\text { Drainages }\end{array}$} & $0-100 \mathrm{~m}$ & 22 & 208,906 & -0.277 & 7.355 \\
\hline & $100-200 \mathrm{~m}$ & 26 & 117,276 & 0.466 & 9.542 \\
\hline & $200-300 \mathrm{~m}$ & 6 & 45,653 & -0.056 & 7.706 \\
\hline & $300-400 \mathrm{~m}$ & 0 & 11,475 & $-3.0 *$ & -12.807 \\
\hline & $>400 \mathrm{~m}$ & 0 & 3,624 & $-3.0 *$ & $0^{\#}$ \\
\hline \multirow{3}{*}{ Lineament Density } & $0-1,500 \mathrm{~m} / \mathrm{km}^{2}$ (low) & 25 & 218,078 & -0.192 & 4.725 \\
\hline & $1,500-3,000 \mathrm{~m} / \mathrm{km}^{2}$ (moderate) & 29 & 153,951 & 0.303 & 4.578 \\
\hline & $>3,000 \mathrm{~m} / \mathrm{km}^{2}$ (high) & 0 & 14,905 & $-3.0 *$ & $0^{\#}$ \\
\hline \multirow{5}{*}{$\begin{array}{l}\text { Distance from } \\
\text { Lineaments }\end{array}$} & $0-100 \mathrm{~m}$ & 7 & 80,975 & -0.474 & -0.235 \\
\hline & $100-200 \mathrm{~m}$ & 10 & 69,288 & 0.037 & 1.028 \\
\hline & $200-300 \mathrm{~m}$ & 15 & 59,410 & 0.596 & 0.088 \\
\hline & $300-400 \mathrm{~m}$ & 10 & 46,820 & 0.429 & 0.906 \\
\hline & $>400 \mathrm{~m}$ & 12 & 130,967 & -0.416 & $0^{\#}$ \\
\hline
\end{tabular}

* arbitrary value as filler for In

\# arbitrary value as filler for $\beta$

Constant for logistic regression analysis -28.723

The role of geomorphology is very important in conditioning the terrain for denudational processes of the area. Geomorphological features such as side slope plateau (0.512) and denudational hills (0.797) are showing maximum InfoVal weights while in the MLR analysis maximum influence is shown by the denudational hill (8.094) followed by denudational slope, escarpments and side slope plateau, which makes the terrain more susceptible to landslide. The analysis of influence of land use/land cover type in the area towards conditioning the terrain for landside through the InfoVal technique shows the maximum influence of the class bushes and shrubs (0.763) followed by cleared/barren area (0.653). The tabulated data of landslide distribution in each class show that the maximum landslide occurrence $(57 \%$ of the total landslides) was observed in rubber plantation but has shown minimum weightage in the analysis. This is due to the fact that the majority of the area $(69 \%)$ is covered with rubber plantations, and while considering the area ratio with number ratio, the effect has been brought into a very low value. The classified soil thickness map indicates the maximum values in the class range between 1 and $2.5 \mathrm{~m}$ in the InfoVal analysis whereas the multiple logistic regression coefficient for the soil thickness classes shows 
negative values, in which the maximum number of landslide occurrence was noticed in the class 1-2.5 m. Five digital elevation derivatives were used to analyse individually to identify the contribution of each of the parameters in making the terrain susceptible to landslide. The assessment of InfoVal weights shows that number of landslides occurred in the slope range of $20-25^{\circ}$, which is considered to be a critical range in the terrain. In the InfoVal method, the aspect was classified into nine discrete classes, and in MLR it was considered as a continuous variable. The slope directional classes, N, SW, W and NW, are showing high values in InfoVal analysis. From the MLR analysis, the impact factor of aspect was derived as 0.003 . In the case of relative relief, more number of landslide occurrences was reported above the relative relief class $>300 \mathrm{~m} / \mathrm{km}^{2}$, and all the class ranges above this show the high value of InfoVal weight. At the same time, in MLR, a value of 0.008 was derived as the weight factor for relative relief. The relationship between terrain curvatures (plan and profile curvatures) and landslide occurrence was also assessed, but this factor had not much influence over landslide occurrence in the region and, therefore, was omitted from the further analysis.

In the study area, most of the landslide initiation locations were observed in association with the mountain streams. In order to rate the influence of drainages on landslide occurrence, both the drainage density and distance from drainages were considered in the analysis. In the InfoVal and MLR analysis, a larger number of landslide occurrences were noticed in the lower drainage density zone and a distance below $200 \mathrm{~m}$ from drainages. The weight values for low drainage density zones are 0.138 and 10.833 , respectively, for InfoVal and MLR analysis. At the same time, the variable distance from drainages showed maximum InfoVal rating of 0.466 in the range of 100-200 $\mathrm{m}$. The weight factor derived by the MLR analysis also shows maximum value (9.542) in the same class as those shown by the InfoVal analysis. The relationship between lineament density and the previous landslide locations indicates that the low and moderate lineament density zones contain whole the past landslides which occurred in the area with high InfoVal weight for medium landslide density class (0.303), while in the MLR weight maximum value was observed in the low density (4.725) class followed by medium density (4.578). In the case of landslide occurrence points with distance from lineaments, the maximum correlation was observed in the class range between 200-300 m and $300-400 \mathrm{~m}$ in the InfoVal analysis (0.596 and 0.429, respectively), and that in the MLR analysis varies to 100-200 m (1.028) followed by 300-400 m (0.906).

\section{$5 \quad$ Results and discussion}

To evaluate the contribution of each factor towards landslide susceptibility, the existing landslide distribution data layer (54 numbers of landslides) has been compared to various thematic data layers separately. The number of landslide pixels falling in each class of the thematic data layers has been recorded and weights have been calculated on the basis of InfoVal and multiple logistic regression (MLR) techniques. Weighted thematic maps in raster format were integrated in the raster calculator using the map algebra given in equations (5) and (6) and used for the preparation of landslide susceptibility index (LSI) maps.

$$
\begin{aligned}
& L S I_{\text {InfoVal }}=\text { Geom }_{I W}+L U L C_{I W}+S T k_{I W}+S l p_{I W} \\
&+\operatorname{Asp}_{I W}+R P_{I W}+P l C_{I W} \\
&+\operatorname{ProfC}_{I W}+\operatorname{DrDen}_{I W} \\
&+\operatorname{DrDist}_{I W}
\end{aligned}
$$

$$
\begin{aligned}
L S I_{M L R}=-28.72 & + \text { Geom }_{M L R}+L U L C_{M L R} \\
& + \text { STk }_{M L R}+\operatorname{Slp}_{M L R}+\text { Asp } x 0.03 \\
& + \text { RRx } 0.008+P l C x-1.471 \\
& +\operatorname{ProfCx}-1.091+\text { DrDen }_{M L R} \\
& + \text { LmDen }_{M L R}+\text { LmDist }_{M L R}
\end{aligned}
$$

where Geom is geomorphology, LULC is land use/land cover, STk is soil thickness, $S l p$ is slope, Asp is aspect, $R R$ is relative relief, $P l C$ is plan curvature, ProfC is profile curvature, DrDen is drainage density, DrDist is distance from drainages, LmDen is lineament density, LmDist is distance from lineaments, $I W$ is InfoVal weights, $M L R$ is MLR coefficients, and -28.723 is a constant. Thus, two landslide susceptibility index maps representing the InfoVal and MLR techniques have been produced.

The prepared landslide susceptibility index map for InfoVal technique is found to be varying between -16.86 and 7.46. At the same time, the landslide susceptibility index map generated through the MLR technique shows minimum and maximum value ranges between -46.67 and 14.35 . With the higher LSI value susceptibility to landslide will be high while negative and zero values indicate nil to low landslide initiation susceptibility. In order to determine and identify the spatial distribution of different landslide susceptibility zones (LSZ), both the LSI maps were segmented into five representative classes. The segmentation was done by analysing the overall distribution pattern, shape of the cumulative frequency curve of susceptibility index values and applying the field knowledge and expert opinion. Five landslide susceptibility classes representing stable, low, moderate, high and critical landslide susceptible zones (Fig. 5) were derived, and the details are provided in Table 2 .

The critical landslide susceptible zone occupies $5.54 \%$ and $8.23 \%$ of the total area in LSZ maps prepared by InfoVal and MLR techniques, respectively, which denotes the influence of the side slope plateau, denudational hill, slope more than $25^{\circ}$ and high relative relief. Highly susceptible zones occupy $26.69 \%$ and $19.2 \%$ of the total area, respectively, for InfoVal and MLR susceptible maps. These zones are characterised by the area with slope $>25^{\circ}$, relative relief $>300 \mathrm{~m} / \mathrm{km}^{2}$, denudational hills 

in the Western Ghats

and denudational slopes. Other susceptible zones like moderate and low occupy $21.67 \%, 17.27 \%$ and $22.43 \%, 15.86 \%$ of the total area. In this, moderate susceptibility zones also need careful observation and proper planning while performing any developmental activities. The stable area occupies $28.83 \%$ in the LSZ map of InfoVal and $34.18 \%$ in LSZ map of MLR technique.

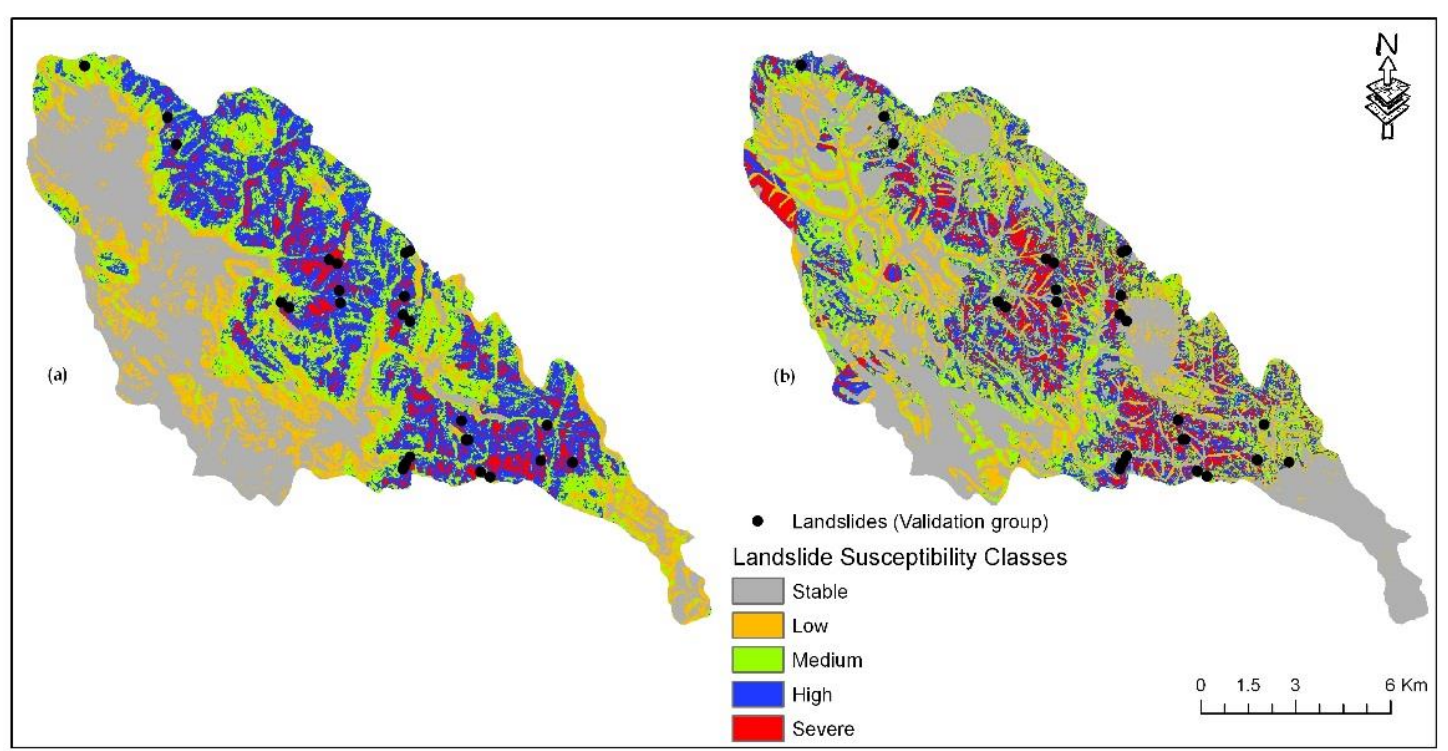

Figure 5. Classified landslide susceptibility zonation (LSZ) maps with validation group of landslides: (a) InfoVal technique and (b) multiple logistic regression (MLR) technique.

Table 2. $\quad$ Area distribution of landslide susceptibility zones (LSZ) with percentage distribution of the validation of group of landslides in each zone.

\begin{tabular}{||c|c|c|c|c|c|c|c||}
\hline $\begin{array}{c}\text { Landslide } \\
\begin{array}{c}\text { Susceptibility } \\
\text { Class }\end{array}\end{array}$ & $\begin{array}{c}\text { Landslide } \\
\text { Susceptibility } \\
\text { Index Range }\end{array}$ & \multicolumn{2}{|c|}{ InfoVal } & \multicolumn{2}{c|}{ MLR } & \multicolumn{2}{c|}{$\begin{array}{c}\text { \% of Validation } \\
\text { group of } \\
\text { landslides }\end{array}$} \\
\hline & $\begin{array}{c}\text { InfoVal and } \\
\text { MLR }\end{array}$ & $\begin{array}{c}\text { Area } \\
\left(\mathrm{km}^{2}\right)\end{array}$ & $\begin{array}{c}\text { Area } \\
(\%)\end{array}$ & $\begin{array}{c}\text { Area } \\
\left(\mathrm{km}^{2}\right)\end{array}$ & $\begin{array}{c}\text { Area } \\
(\%)\end{array}$ & InfoVal & MLR \\
\hline Stable & $-16--6$ & 44.69 & 28.83 & 52.97 & 34.18 & 0 & 15.38 \\
\hline Low & $-6--3$ & 26.76 & 17.27 & 24.58 & 15.86 & 3.85 & 11.54 \\
\hline Medium & $-3-0$ & 33.58 & 21.67 & 34.77 & 22.43 & 23.08 & 11.54 \\
\hline High & $0-3$ & 41.37 & 26.69 & 29.78 & 19.21 & 46.15 & 50.00 \\
\hline Severe & $>3$ & 8.59 & 5.54 & 12.89 & 8.32 & 26.92 & 11.54 \\
\hline
\end{tabular}

The performance and predictive capacity of the landslide susceptibility zonation maps were tested using the estimation set of landslide location (54 numbers) used for the preparation of landslide susceptibility zonation maps (success rate curves) and a set of validation group of landslides (26 numbers) kept to check the predictive power of landslide susceptibility zonation maps (prediction rate curves) and the suitability of methods in the area. The success rate curve explains how well the model and the factor predict the landslides, and the prediction rate curve indicates the success rate and predictive power of the model in terms of accuracy. In order to estimate the success rate and prediction rate of the models, classified final landslide susceptibility maps were crossed with the estimation and validation group of landslides separately. Based on a given LSZ map, the success and prediction rate curves (Lu and An, 1999; Remondo et al., 2003; Vijith and Madhu, 2007), which represent the cumulative percentage of landslide occurrence in various susceptibility classes in (y-axis) against the cumulative percentage of the area of the susceptibility classes in (x-axis), were generated. The area under a curve (AUC) was used to measure the prediction accuracy (success rate) of the model qualitatively (Fig. 6a).

The area ratio for the LSZ created by InfoVal techniques is 0.8411 and the success rate of the models is $84.11 \%$. The area ratio calculated for LSZ map generated by multiple logistic regression (MLR) technique is 0.6865 , and the success rate of the model is $68.65 \%$. It was also noted that in the success rate curve of InfoVal derived susceptibility map the stable area is devoid of landslide occurrence and the low landslide susceptibility zone contains only $1.85 \%$ of the total landslide (1 out of 54). Similarly, in the case of susceptibility map prepared by MLR method, stable zone contains $5.55 \%$ (3 out of 54) of landslide occurrence and low landslide susceptibility zone contain $9.25 \%$ (5 out of 54) of the total landslide used for the preparation of LSZ maps. This can be considered as the first-order error, and the effect will be very less and hence the result is acceptable. The result indicates the usability of InfoVal technique over the MLR method in LSZ mapping in this region. 

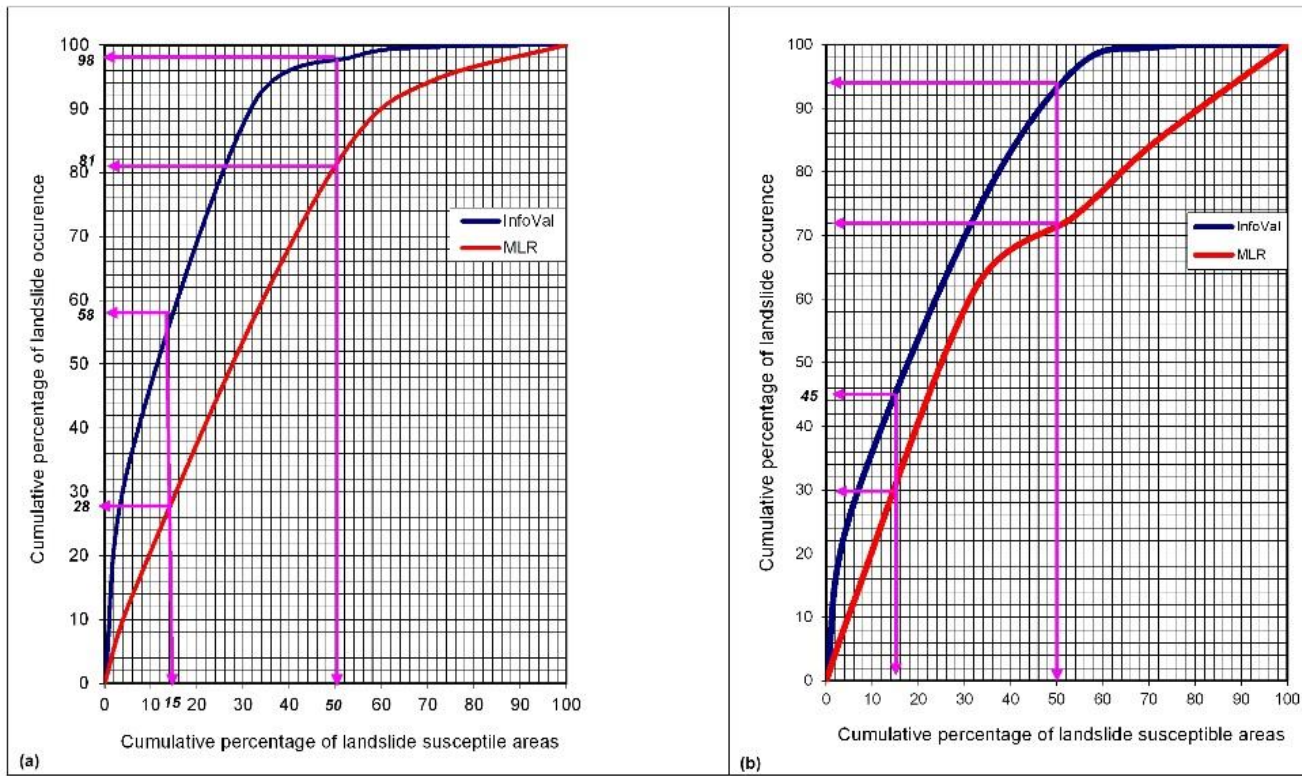

Figure 6. Cumulative frequency diagrams showing percentage of study area classified as susceptible (x-axis) in cumulative per cent of landslide (validation group) occurrence (y-axis): (a) success rate curves; (b) prediction rate curve.

While preparing the prediction rate curve (Figure $6 \mathrm{~b}$ ), it was noted that, the maximum number of validation group of the landslide was occurring in the highly susceptible zone (12 and 13 numbers of landslide events respectively for InfoVal and MLR maps) followed by severe and moderate susceptibility zones. At the same time, the stable landslide susceptibility class in the MLR map shows the presence of $15 \%$ of the validation group of landslides, which was considered as wrongly classified. The graphs indicate the capability of the two models to classify the terrain based on the landslide susceptibility and classify the terrain based on proneness to landslide. From the graph, two cases of landslide prediction condition were evaluated for both the LSZ maps. In the first condition, 15\% of high landslide susceptible area is capable of accommodating $45 \%$ and $30 \%$ of total validation group of landslides. In the second condition, 50\% of the landslide susceptible areas are able to accommodate $94 \%$ and $72 \%$ of total validation group of landslides that occurred in the area respectively for LSZ map produced by InfoVal and MLR techniques. In the case of prediction rate curve prepared using the validation group of landslides, the area ratio (area under curve) for the LSZ created by InfoVal techniques is 0.826 and the success rate of the models is $82.60 \%$. The area ratio calculated for LSZ map generated by multiple logistic regression (MLR) technique is 0.648 and the success rate of the model is $64.80 \%$. The first-order errors of the models were assessed quantitatively by counting the occurrence of landslide events in stable and low landslide susceptibility zones. It was observed that, in the InfoVal derived susceptibility map, the stable areas are devoid of landslide occurrence and the low landslide susceptibility zone comprise only $3.85 \%$ of the total landslides ( 1 out of 26). In the case of LSZ prepared by MLR method, stable zone accounts for $15.38 \%$ (4 out of 26) of landslide occurrence and low landslide susceptibility zone accounts for $11.54 \%$ (3 out of 26) of the total landslide used for the validation of the landslide susceptibility zonation map. The comparison of the AUC curve and quantitative accuracy of the model shows that the LSZ map produced by the InfoVal technique shows a generally more acceptable accuracy compared to LSZ generated by MLR techniques and is supported by the first order error computed for both the susceptibility maps.

\section{Conclusions}

In this study, it was attempted to evaluate the best suitable methodology for the assessment of shallow landslide initiation susceptibility in the Western Ghats, India, by comparing the bivariate (InfoVal) with multivariate (multiple logistic regression) statistical techniques. Both the techniques used the same dependant and independent variables to analyse and establish the relative importance of landslide conditioning terrain factors. The assessment of statistical importance of landslide conditioning terrain variable and its classes carried out using the different techniques, and it was found that variables such as geomorphology, land use, soil thickness, slope, relative relief, drainage density, distance from drainages and lineament density are influencing landslide susceptibility of the region under study. It was also noted that among the crucial variables identified, selective classes such as side slope plateau and denudational hills with slope greater than $20^{\circ}$, soil thickness less than $2.5 \mathrm{~m}$, high relative relief, low to moderate drainage and lineament density, and 
distance near to drainages were marked with a maximum incidence of landslides and have high influence in the landslide susceptibility zonation maps prepared.

The LSZ maps generated by InfoVal and MLR techniques show various dimensions and spatial pattern of different landslide susceptibility zones, in which the severe and high susceptibility zones occupy $5.54 \%, 26.69 \%$ and $8.32 \%, 19.21 \%$ of the total area, respectively for InfoVal and MLR based LSZ maps. The success rate of the proposed models and validation of the LSZ maps produced were assessed through the area under curve technique. In both maps produced, the InfoVal method dominates over the MLR techniques with $84.11 \%$ success rate and $82.60 \%$ of accuracy. Landslide susceptibility zonation map produced through the MLR method shows $68.65 \%$ and $64.80 \%$, respectively for success rate and accuracy. The findings of the study coupled with the assessment of first order errors of the models indicate the dominated applicability, suitability and reliability of the bivariate statistical technique over the multivariate techniques in producing a landslide susceptibility zonation maps and its replicability in terrains having similar geo-environmental and climatic conditions, where the data collection is difficult and historical data records are scarce.

\section{Acknowledgments}

The first author is grateful to the Head of the State Emergency Operation Centre (SEOC), Kerala State Disaster Management Authority, Department of Revenue and Disaster Management, for providing constant inspiration. The authors are grateful to anonymous reviewers for constructive comments and suggestions.

\section{References}

Akbar, Ta. and Ha, Sr. (2011) Landslide hazard zoning along Himalayan Kaghan Valley of Pakistan-by integration of GPS, GIS, and remote sensing technology. Landslides 8(4): 527-540. doi: http://dx.doi.org/10.1007/s10346-011-0260-1.

Akgun, A., Kincal, C., and Pradhan, B. (2012) Application of remote sensing data and GIS for landslide risk assessment as an environmental threat to Izmir city (west Turkey). Environmental Monitoring and Assessment 184(9): 5453-5470. doi: http://dx.doi.org/ 10.1007/s10661-011-2352-8.

Akgun, A.A. (2012) Comparison of landslide susceptibility maps produced by logistic regression, multi-criteria decission, and likelihood ratio methods: a case study at İzmir, Turkey. Landslides 9: 93-106. doi: http://dx.doi.org/10.1007/s10346-011-0283-7.

Aleotti, P. and Chowdhury, R. (1999) Landslide hazard assessment: summary review and new perspectives. Bulletin of Engineering Geology and Environment 58: 21-44. doi: http://dx.doi.org/10.1007/s100640050066.

Althuwaynee, O.F., Pradhan, B., and Lee, S. (2010) Application of an evidential belief function model in landslide susceptibility mapping. Computer and
Geosciences 44: 120-135. doi: http://dx.doi.org/ 10.1016/j.cageo.2012.03.003.

Ayalew, L. and Yamagishi, H. (2005) The application of GIS-based logistic regression for landslide susceptibility mapping in the Kakuda-Yahiko Mountains, Central Japan. Geomorphology 65(1-2): 15-31. doi: http://dx.doi.org/10.1016/j.geomorph.2004.06.010.

Brenning, A. (2005) Spatial prediction models for landslide hazards: review, comparison and evaluation. Natural Hazards and Earth System Sciences 5: 853-862. doi: http://dx.doi.org/10.5194/nhess-5-853-2005.

Carrara, A. (1983) Multivariate models for landslide hazard evaluation. Mathematical Geology 15(3): 403-427. doi: http://dx.doi.org/10.1007/BF01031290.

Carrara, A., Cardinali, M., Detti, R., Guzzetti, F., Pasqui, V., and Reichenbach, P. (1991) GIS techniques and statistical models in evaluating landslide hazard. Earth Surface Processes and Landforms 16: 427-445. doi: http://dx.doi.org/10.1002/esp.3290160505.

Dahal, R.K., Hasegawa, S., Nonomura, A., Yamanaka, M., Masuda, T., and Nishino, K. (2008) GIS-based weightsof-evidence modelling of rainfall-induced landslides in small catchments for landslide susceptibility mapping. Environmental Geology 54: 311-324. http://dx.doi.org/ 10.1007/s00254-007-0818-3.

Das, I., Sahoo, S., van Westen, C., Stein, A., and Hack, R. (2010) Landslide susceptibility assessment using logistic regression and its comparison with a rock mass classification system, along a road section in the northern Himalayas (India). Geomorphology 114(4): 627-637. doi: http://dx.doi.org/10.1016/j.geomorph. 2009.09.023.

Devkota, K.C., Regmi, A.D., Pourghasemi, H.R., Yoshida, K., Pradhan, B., Ryu, I.C., Dhital, M.R., and Althuwaynee, O.F. (2013) Landslide susceptibility mapping using certainty factor, index of entropy and logistic regression models in GIS and their comparison at Mugling-Narayanghat road section in Nepal Himalaya. Natural Hazards 65: 135-165. doi: http://dx.doi.org/10.1007/s11069-012-0347-6.

Duman, T.Y., Can, T., Gokceoglu, C., Nefeslioglu, H.A. and Sonmez, H. (2006) Application of logistic regression for landslide susceptibility zoning of Cekmece Area, Istanbul, Turkey. Environmental Geology 51(2): 241-256. doi: http://dx.doi.org/ 10.1007/s00254-006-0322-1.

Ercanoglu, M. and Temiz, F.A. (2011) Application of logistic regression and fuzzy operators to landslide susceptibility assessment in Azdavay (Kastamonu, Turkey). Environmental Earth Sciences 64(4): 949-964. doi: http://dx.doi.org/10.1007/s12665-011-0912-4.

Gokceoglu, C. and Aksoy, H. (1996) Landslide susceptibility mapping of the slopes in the residual soils of the Mengen region (Turkey) by deterministic stability analyses and image processing techniques. Engineering Geology 44: 147-161. doi: http://dx.doi.org/10.1016/ S0013-7952(97)81260-4.

Gorsevski, P.V., Foltz, R.B., Gessler, P.E., and Elliot, W.J. (2006) Spatial Prediction of landslide hazard using logistic regression and ROC analysis. Transactions in GIS 10(3): 395-415. doi: http://dx.doi.org/10.1111/ j.1467-9671.2006.01004.x.

Guinau, M., Palla'S, R., and Vilaplana, J.M. (2005) A feasible methodology for landslide susceptibility assessment in developing countries: A case-study of NW Nicaragua after Hurricane Mitch. Engineering Geology 80: 316- 327. doi: http://dx.doi.org/ 10.1016/j.enggeo.2005.07.001.

Guzzetti, F., Carrara, A. and Reichenbach, P. (1999) Landslide hazard evaluation: a review of current 
techniques and their application in a multi-case study, Central Italy. Geomorphology 31: 181-216. doi: http://dx.doi.org/10.1016/S0169-555X(99)00078-1.

Huabin, W., Gangjun, L., Weiya, X., and Gonghui, W. (2005) GIS-based landslide hazard assessment: an overview. Progress in Physical Geography 29(4): 548567. doi: http://dx.doi.org/10.1191/0309133305pp462ra.

Kannan, M., Saranathan, E., and Anbalagan, R. (2014) Comparative analysis in GIS-based landslide hazard zonation - a case study in Bodi-Bodimettu Ghat section, Theni District, Tamil Nadu, India. Arabian Journal of Geosciences. doi: 10.1007/s12517-013-1259-9. doi: http://dx.doi.org/10.1007/s12517-013-1259-9.

Kundu, S., Saha, A.K., Sharma, D.C., and Pant, C.C. (2013) Remote Sensing and GIS Based Landslide Susceptibility Assessment using Binary Logistic Regression Model: A Case Study in the Ganeshganga Watershed, Himalayas. Journal of the Indian Society of Remote Sensing 41(3): 697-709. doi: http://dx.doi.org/ 10.1007/s12524-012-0255-y.

Kuriakose, S.L., Sankar, G., and Muraleedharan, C. (2009) History of landslide susceptibility and a chorology of landslide-prone areas in the Western Ghats of Kerala, India. Environmental Geology 57(7): 1553-1568. doi: http://dx.doi.org/10.1007/s00254-008-1431-9.

Mathew, J., Jha, V.K., and Rawat, G.S. (2009) Landslide susceptibility zonation mapping and its validation in part of Garhwal Lesser Himalaya, India, using binary logistic regression analysis and receiver operating characteristic curve method. Landslides 6(1): 17-26. doi: http://dx.doi.org/10.1007/s10346-008-0138-z.

Nagarajan, R., Mukherjee, A., Roy, A., and Khire, M.V. (1998) Temporal remote sensing data and GIS application in landslide hazard zonation of part of Western Ghat, India. International Journal of Remote Sensing 19: 573-585. doi: http://dx.doi.org/10.1080/ 014311698215865 .

Nandi, A. and Shakoor, A.A (2010) GIS-based landslide susceptibility evaluation using bivariate and multivariate statistical analyses. Engineering Geology 110(1-2): 11-20. doi: http://dx.doi.org/10.1016/ j.enggeo.2009.10.001.

Nefeslioglu, H.A., Gokceoglu, C. And Sonmez, H. (2008) An assessment on the use of logistic regression and artificial neural networks with different sampling strategies for the preparation of landslide susceptibility maps. Engineering Geology 97(3-4): 171-191. doi: http://dx.doi.org/10.1016/j.enggeo.2008.01.004.

Ozdemir, A. and Altural, T. (2013) A comparative study of frequency ratio, weights of evidence and logistic regression methods for landslide susceptibility mapping: Sultan Mountains, SW Turkey. Journal of Asian Earth Sciences 64(5): 180-197. doi: http://dx.doi.org/10.1016/ j.jseaes.2012.12.014.

Pourghasemi, H.R., Pradhan, B., Gokceoglu, C., Mohammadi, M., and Moradi, H.R. (2013) Application of weights-of-evidence and certainty factor models and their comparison in landslide susceptibility mapping at Haraz watershed, Iran. Arabian Journal of Geosciences 6(7): 2351-2365. doi: http://dx.doi.org/10.1007/s12517012-0532-7.

Prasannakumar, V. and Vijith, H. (2012) Evaluation and validation of landslide spatial susceptibility in the Western Ghats of Kerala, through GIS-based Weights of Evidence model and area under curve technique. Journal of the Geological Society of India 80(4): 515523. doi: http://dx.doi.org/10.1007/s12594-012-0171-3.

Saha, A.K., Gupta, R.P., Sarkar, I., Arora, M.K., and Csaplovica, E. (2005) An approach for GIS-based statistical landslide susceptibility zonation - with a case study in the Himalayas. Landslides 2(1): 61-69. doi: http://dx.doi.org/10.1007/s10346-004-0039-8.

Sarkar, S. and Kanungo, D.P. (2004) An integrated approach for landslide susceptibility mapping using remote sensing and GIS. Photogrammetric Engineering and Remote Sensing 70: 617-625. doi: http://dx.doi.org/ 10.14358/PERS.70.5.617.

Thampi, P.K., John, M., Sankar, G., and Sidharthan, S. (1998) Evaluation Study in terms of landslide mitigation in parts of Western Ghats, Kerala. Report submitted to the Ministry of Agriculture, Govt. of India.

van Westen, C.J. (1997). Statistical landslide hazard analysis. In: ITC (1997). ILWIS 2.1 for Windows: The Integrated Land and Water Information System. Applications Guide (pp. 73-84). Enschede, The Netherlands: ILWIS Department, ITC.

van Westen, C.J. (2000) The modelling of landslide hazards using GIS. Surveys in Geophysics 21: 241-255. doi: http://dx.doi.org/10.1023/A:1006794127521.

van Westen, C.J., Rengers, N., and Soeters, R. (2003) Use of Geomorphological Information in Indirect Landslide Susceptibility Assessment. Natural Hazards 30: 399_ 419. doi: http://dx.doi.org/10.1023/B:NHAZ. 0000007097.42735.9e.

van Westen, C.J., van Asch, T.W.J., and Soeters, R. (2006) Landslide hazard and risk zonation-why is it still so difficult?. Bulletin of Engineering Geology and the Environment 65: 167-184. doi: http://dx.doi.org/ 10.1007/s10064-005-0023-0.

Varnes, D.J. (1984). Landslide hazard zonation: a review of principles and practice. IAEG, Commission on landslides and other mass movements, pp. 63, Paris, France: Unesco.

Vijith, H., Rejith, P.G., and Madhu, G. (2007) Using InfoVal method and GIS techniques for the spatial modeling of landslide susceptibility in the upper catchment of river Meenachil in Kerala. Journal Indian Society of Remote Sensing 37: 241-250. doi: http://dx.doi.org/10.1007/s12524-009-0028-4.

Vijith, H. And Madhu, G. (2008) Estimating potential landslide sites of an upland sub-watershed in Western Ghat's of Kerala (India) through frequency ratio and GIS. Environmental Geology 55(7): 1397-1405. doi: http://dx.doi.org/10.1007/s00254-007-1090-2.

Vijith, H., Krishnakumar, K.N., Pradeep, G.S., Ninu Krishnan, M.V., and Madhu, G. (2014) Shallow landslide initiation susceptibility mapping by GIS-based weights-of-evidence analysis of multi-class spatial datasets: a case study from the natural sloping terrain of Western Ghats, India. Georisk: Assessment and Management of Risk for Engineered Systems and Geohazards 8(1): 48-62. doi: http://dx.doi.org/10.1080/ 17499518.2013 .843437$.

Yesilnacar, E. and Topal, T. (2005) Landslide susceptibility mapping: A comparison of logistic regression and neural networks methods in a medium scale study, Hendek region (Turkey). Engineering Geology 79: 251266. doi: http://dx.doi.org/10.1016/j.enggeo.2005.02. 002.

Yilmaz, C., Topal, T. And Süzen, M.L. (2012) GIS-based landslide susceptibility mapping using bivariate statistical analysis in Devrek (Zonguldak-Turkey). Environmental Earth Sciences 65(7): 216-2178. doi: http://dx.doi.org/10.1007/s12665-011-1196-4.

Zezere, J.L. (2002) Landslide susceptibility assessment considering landslide typology. A case study in the area north of Lisbon (Portugal). Natural Hazards and Earth System Sciences 2: 73-82. doi: http://dx.doi.org/ 10.5194/nhess-2-73-2002. 


\title{
Dviejų skirtingų statistinių metodụ tinkamumo paviršiniụ nuošliaužų pradžios jautrumui Vakarų Gatuose matuoti nustatymas
}

\author{
Ninu Krishnan M. V. ${ }^{1}$, Pratheesh P. ${ }^{2}$, Rejith P. G. ${ }^{3}$, Hamza V., \\ ${ }^{I}$ Valstybinis ekstremaliuju situaciju operaciju centras (SEOC), Keralos valstijos stichiniu nelaimiu valdymo \\ tarnyba, Žemès ir stichiniu nelaimiu valdymo institutas, Kerala, Indija \\ ${ }^{2}$ Geoinformacijos mokslo ir technologiju centras, Keralos universitetas, Kariavattom, Kerala, Indija \\ ${ }^{3}$ Aplinkos ir klimato kaitos departamentas, Keralos Vyriausybe, Kerala, Indija \\ ${ }^{4}$ Taikomosios geologijos departamentas, Inžinerijos ir mokslo fakultetas, Kurtino technologijos universitetas, \\ Saravakas, Malaizija
}

Siekiant nustatyti nuošliaužų jautrumo įvertinimo statistinių metodų tinkamumą pritaikius geografinès informacijos sistemas (GIS) tuose regionuose, kuriuose duomenis gauti sudètinga, buvo naudojami informacinės vertės (InfoVal) ir daugianarès logistinės regresijos (MLR) metodai, pagrịsti dviejų ir daugiau kintamųų statistine analize, paviršinių nuošliaužų pradžios jautrumui pasirinktose vandenskyrose Vakarų Gatuose, Keraloje, Indijoje, nustatyti. Buvo tirti šie skirtingi nuošliaužas lemiantys vietovès kintamieji: geomorfologija, žemės naudojimas ir žemés danga, dirvožemio storis, nuolydis, kryptis, santykinis reljefas, plano kreivumas, profilio kreivumas, drenažo tankumas, atstumas nuo drenažų ir kt. Nuošliaužų jautrumo indekso (LSI) žemėlapiai buvo sukurti integruojant įtaką darančius veiksnius; išskirtos penkios nuošliaužų jautrumo zonos (LSZ) koreliuojant nuošliaužų jautrumo indeksą su bendromis vietovės sąlygomis. InfoVal ir MLR metodais sukurtuose jautrumo žemėlapiuose plotas po sėkmės dydžių kreivėmis (angl. area under success rate curves, AUC) parodè atitinkamai $84,11 \%$ ir $68,65 \%$ reikšmes. Prognozuojamo dydžio kreivès rodo gerą/vidutinę koreliaciją tarp nuošliaužu pasiskirstymo rezultatus patvirtinančios grupès ir LSZ žemėlapių su AUC reikšmėmis, atitinkamai nuo 0,648 iki 0,826 MLR ir InfoVal metodais sukurtiems LSZ žemėlapiams. Atsižvelgiant ị tai, kas geriausiai tinka, ir i modelių tinkamumą tyrimo vietoje kiekybinio spėjimo tikslumu, LSZ žemėlapiai sukurti InfoVal metodu rodo didesni tikslumą nei sukurtieji MLR metodu $(82,60 \%)$, geriau atspindi tikrovę, kai lyginama praktikoje. Todèl InfoVal metodas laikomas tinkamiausiu modeliu nuošliaužų jautrumui tose vietovėse, kurios panašios ì šiame tyrime tirtą vietovę, matuoti. Vietovei sukurtas LSZ žemèlapis gali būti naudojamas regioninio planavimo ir vertinimo procesuose, įtraukiant apibendrintas kritulių sąlygas toje teritorijoje.

Raktiniai žodžiai: Vakaru Gatai, paviršinès nuošliaužos, informacinè vertè, daugianarè logistine regresija, jautrumo juvertinimas. 